Article

\title{
Two New Oleanane-Type Saponins with Anti-Proliferative Activity from Camellia oleifera Abel. Seed Cake
}

\author{
Jian-Fa Zong, Yun-Ru Peng, Guan-Hu Bao, Ru-Yan Hou * and Xiao-Chun Wan * \\ State Key Laboratory of Tea Plant Biology and Utilization, Anhui Agricultural University, Hefei 230036, China; \\ zonjfa@sina.com (J.-F.Z.); pengyunru1101@sina.com (Y.-R.P.); baoguanhu@ahau.edu.cn (G.-H.B.) \\ * Correspondence: hry@ahau.edu.cn (R.-Y.H.); xcwan@ahau.edu.cn (X.-C.W.); \\ Tel./Fax: +86-551-6578-6765 (R.-Y.H. \& X.-C.W.)
}

Academic Editors: Vassilios Roussis and Efstathia Ioannou

Received: 6 January 2016; Accepted: 1 February 2016; Published: 4 February 2016

\begin{abstract}
Two new oleanane-type saponins, named oleiferasaponins $C_{4}(\mathbf{1})$ and $C_{5}(2)$, were isolated from Camellia oleifera Abel. seed cake residue. Their respective structures were identified as $16 \alpha$-hydroxy-22 $\alpha$-O-angeloyl-23 $\alpha$-aldehyde-28-dihydroxymethylene-olean-12-ene-3 $\beta$-O-[ $\beta$-D-galactopyranosyl-( $1 \rightarrow 2)]$-[ $\beta$-D-glucopyranosyl-( $(\rightarrow 2)-\beta$-D-galactopyranosy-( $1 \rightarrow 3)]-\beta$-D-glucopyranosid-uronic acid methyl ester $(\mathbf{1})$ and $16 \alpha$-hydroxy-22 $\alpha$-O-angeloyl-23 $\alpha$-aldehyde-28-dihydroxy-methylene-olean12-ene-3 $\beta$-O-[ $\beta$-D-galactopyranosyl- $(1 \rightarrow 2)]$-[ $\beta$-D-galactopyranosyl- $(1 \rightarrow 3)]-\beta$-D-glucopyranosiduronic acid methyl ester (2) through 1D- and 2D-NMR, HR-ESI-MS, and GC-MS spectroscopic methods. The two compounds exhibited potent cytotoxic activities against five human tumor cell lines (BEL-7402, BGC-823, MCF-7, HL-60 and KB).
\end{abstract}

Keywords: Camellia tea oil; saponin; oleiferasaponins; cytotoxic activity

\section{Introduction}

Camellia oleifera Abel. seed saponins are triterpenoidic natural compounds that have potent pharmacological and biological activities, including antimicrobial [1-3], antioxidant [4], and gastroprotective [5] effects. Camellia saponins are commercially used as biosurfactants [6], biopesticides [7] and detergents [8]. New saponin monomers continue to be isolated and identified from the seed cake of Camellia oleifera, with many showing potent anti-proliferative activity against human cancer cell lines [9-11]. C. oleifera seed cake, is an agricultural byproduct resulting from the extraction of the edible tea oil from the seeds. The seed cake contains approximately $10 \%$ saponins by weight, a fraction comprised of more than 30 types of saponins [3,12]. There are 10 saponins $[1,9,10,12-14]$ that have been recently identified in tea seed cake, including nine previously unreported from any source. Seven of the saponins have been reported to have anti-proliferative activity against human cancer cell lines. A previous study indicated that different tea saponin structures display different anti-tumor activity [15]. Some of the varied saponins in C. oleifera seed cake are more difficult to isolate and have complex chemical structures that are difficult to identify, hindering the study of their structure and function. In order to study the saponin structure-activity relationships, it is necessary to isolate and identify additional monomer compounds from the crude saponin fraction, especially triterpene saponins. Identification of the functions of oleanane-type saponins in C. oleifera and clear illustration of structure-activity relationship would increase the effective utilization of tea cake, particularly in pharmaceutical applications. As a part of our ongoing study of the constituents of the C. oleifera seed cake of, we recently isolated two new oleanane-type saponins. We report herein the isolation and structural elucidation of the new saponins, namely oleiferasaponins $C_{4}$ and $C_{5}$ (Figure 1), along with 
their anti-proliferative activity against five human tumor cell lines, namely BEL-7402, BGC-823, MCF-7, HL-60 and KB.

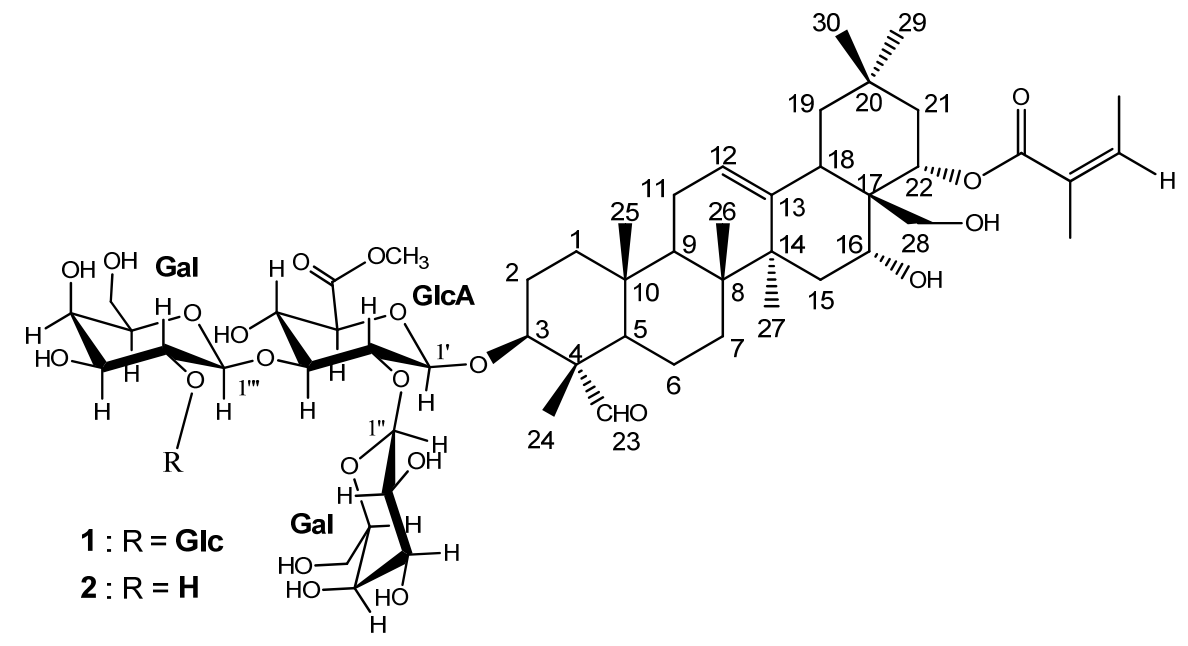

Figure 1. Structures of oleiferasaponins $C_{4}$ and $C_{5}(1,2)$.

\section{Results and Discussion}

\subsection{Isolation and Characterization of the Triterpenoid Saponins}

The $n$ - $\mathrm{BuOH}$ fraction obtained from the $70 \% \mathrm{EtOH}$ extract of defatted seed cake of C. oleifera was further separated through silica gel column and gel permeation chromatography on Sephadex LH-20, and by repeated reversed-phase $C_{18}$ column chromatography. Two new oleanane-type saponins were thus obtained. Their structures were determined mainly by $600 \mathrm{MHz}$ NMR experiments and high resolution electro-spray ionization mass spectrometry (HR-ESI-MS).

Compound 1 was separated as a white amorphous powder. The molecular formula $\mathrm{C}_{60} \mathrm{H}_{94} \mathrm{O}_{27}$ was deduced from the HR-ESI-MS $[\mathrm{M}+\mathrm{Na}]^{+}$ion at $m / z 1269.5875$. The IR spectrum $\left(\mathrm{cm}^{-1}\right)$ showed the presence of hydroxyl (broad peak around 3416), carbonyl (1719), olefinic (1640), and ether $(1078,1044)$ functional groups. The ${ }^{13}$ C-NMR spectrum (Table 1) displayed the resonances of 60 carbons, ascribable to nine methyls, twelve methylenes, twenty-nine methines, and ten quaternary carbons as revealed by the HSQC experiment. Of the 60 carbons, 30 were assigned to the triterpene moiety. The ${ }^{1} \mathrm{H}-\mathrm{NMR}$ spectrum (Table 1 ) showed six methyl groups at $\delta 0.78,0.81,1.05,1.29,1.42$, and $1.80\left(3 \mathrm{H}\right.$, each, all s, $\left.\mathrm{H}_{3}-25,26,29,30,24,27\right)$, one methylene group at $\delta 3.54,3.66(2 \mathrm{H}$, both $\mathrm{m}$, $\left.\mathrm{H}_{2}-28\right)$, three methine protons bearing oxygens at $\delta 4.02(1 \mathrm{H}, \mathrm{m}, \mathrm{H}-3), 4.60(1 \mathrm{H}, \mathrm{br} \mathrm{s}, \mathrm{H}-16)$, and 6.22 $(1 \mathrm{H}, \mathrm{dd}, J=12.0,6.0 \mathrm{~Hz}, \mathrm{H}-22)$, an aldehyde signal at $\delta 9.91(1 \mathrm{H}, \mathrm{s}, \mathrm{H}-23)$, and one olefinic proton signal at $\delta 5.35(1 \mathrm{H}$, br s, H-12), which indicated an oleanane aglycone. Furthermore, the signals of angeloyl (Ang) group at [ $\delta 5.92(1 \mathrm{H}$, dq-like, 22-O-Ang-3), $2.09(3 \mathrm{H}, \mathrm{d}, J=7.2 \mathrm{~Hz}, 22-\mathrm{O}-\mathrm{Ang}-4)$, $1.95(3 \mathrm{H}, \mathrm{s}, 22-\mathrm{O}$-Ang-5) were observed. The location of the Ang group at C-22 was confirmed by the $\mathrm{HMBC}$ experiment (Figure 2). In addition to these, the anomeric proton signals at $\delta_{\mathrm{H}} 4.80$ $\left(1 \mathrm{H}, \mathrm{d}, J=7.2 \mathrm{~Hz}, \mathrm{H}-1^{\prime}\right.$ of glucuronic acid), $5.13\left(1 \mathrm{H}, \mathrm{d}, J=7.8 \mathrm{~Hz}, \mathrm{H}-1^{\prime \prime \prime \prime}\right.$ of glucose), $5.75(1 \mathrm{H}, \mathrm{d}$, $J=7.2 \mathrm{~Hz}, \mathrm{H}-1^{\prime \prime \prime}$ of galactose), and $5.79\left(1 \mathrm{H}, \mathrm{d}, J=7.8 \mathrm{~Hz}, \mathrm{H}-1^{\prime \prime}\right.$ of galactose), which showed the

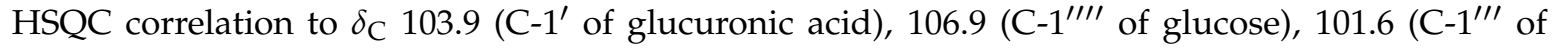
galactose), and 103.1 (C-1" of galactose), respectively, indicated the presence of four sugar residues (Table 1). The position of the sugar components was determined on the basis of the HMBC experiment (Figure 2), which showed long-range correlations between the following proton and carbon pairs: GlcA-H-1 $1^{\prime}$ and $\delta_{\mathrm{C}} 84.1$ (C-3 of the aglycone), indicating that the glycosidic chain was located at

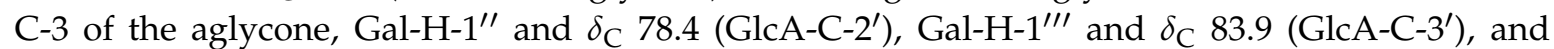
Glc-H-1'"' and $\delta_{\mathrm{C}} 83.5$ (Gal-C-2'). Moreover, the signals at $\delta_{\mathrm{C}} 52.1$ and $\delta_{\mathrm{H}} 3.69$ were identified 
as those of one $\mathrm{OCH}_{3}$ group located at $\mathrm{C}-6^{\prime}$ of the glucuronic acid, which was supported by the HMBC correlation between $\delta_{\mathrm{C}} 170.0\left(\mathrm{GlcA}-\mathrm{C}-6^{\prime}\right)$ and $\delta_{\mathrm{H}} 3.69\left(\mathrm{OCH}_{3}\right)$ (Figure 2). These data from compound 1 were further confirmed by acid hydrolysis and GC-MS analysis, which revealed one unit of D-glucuronic acid methyl ester, two units of D-galactose, and one unit of D-glucose. The relative configuration of $\mathbf{1}$ was established from its NOESY spectrum (Figure 2). The cross peaks between $\mathrm{H}-22$ at $\delta_{\mathrm{H}} 6.22$ and $\mathrm{H}-30$ at $\delta_{\mathrm{H}} 1.29$, as well as those between $\mathrm{H}-16$ at $\delta_{\mathrm{H}} 4.60$ and $\mathrm{H}-28$ at $\delta_{\mathrm{H}} 3.54,3.66$, suggested that $\mathrm{H}-22$ and $\mathrm{H}-16$ are both $\beta$-oriented, which means that the Ang group at $\mathrm{C}-22$ and $16-\mathrm{OH}$ group are both $\alpha$-orientations. The $\mathrm{H}-3$ at $\delta_{\mathrm{H}} 4.02$ correlated with $\mathrm{H}-23$ at $\delta_{\mathrm{H}} 9.91$, indicating that the glycosidic chain group at $\mathrm{C}-3$ is $\beta$-configured. Thus, the structure of 1 was elucidated to be $16 \alpha$-hydroxy-22 $\alpha$-O-angeloyl-23 $\alpha$-aldehyde-28-dihydroxy-methyleneolean12-ene-3 $\beta$-O-[ $\beta$-D-galactopyranosyl- $(1 \rightarrow 2)]$-[ $\beta$-D-glucopyranosyl-( $1 \rightarrow 2)-\beta$-D-galacto-pyranosy- $(1 \rightarrow 3)]-$ $\beta$-D-glucopyranosiduronic acid methyl ester, which is a new compound that we named oleiferasaponin $C_{4}$.

Table 1. ${ }^{1} \mathrm{H}$ - and ${ }^{13} \mathrm{C}-\mathrm{NMR}$ spectroscopic data of oleiferasaponins $\mathrm{C}_{4}$ and $\mathrm{C}_{5}$ in $\mathrm{C}_{5} \mathrm{D}_{5} \mathrm{~N}$.

\begin{tabular}{|c|c|c|c|c|}
\hline \multirow{2}{*}{ Position } & \multicolumn{2}{|c|}{ Oleiferasaponin $\mathrm{C}_{4}(\mathbf{1})$} & \multicolumn{2}{|c|}{ Oleiferasaponin $C_{5}(2)$} \\
\hline & $\delta_{\mathbf{C}}$ & $\delta_{\mathbf{H}}$ & $\delta_{\mathbf{C}}$ & $\delta_{\mathbf{H}}$ \\
\hline 1 & 38.0 & $0.87 \mathrm{~m}, 1.37 \mathrm{~m}$ & 38.0 & $0.90 \mathrm{~m}, 1.41 \mathrm{~m}$ \\
\hline 2 & 25.1 & $1.78 \mathrm{~m}, 2.05 \mathrm{~m}$ & 25.1 & $1.83 \mathrm{~m}, 2.05 \mathrm{~m}$ \\
\hline 3 & 84.1 & $4.02 \mathrm{~m}$ & 84.5 & $4.04 \mathrm{~m}$ \\
\hline 4 & 55.0 & & 55.0 & \\
\hline 5 & 48.3 & $1.37 \mathrm{~m}$ & 48.5 & $1.37 \mathrm{~m}$ \\
\hline 6 & 20.3 & $0.90 \mathrm{~m}, 1.35 \mathrm{~m}$ & 20.3 & $0.96 \mathrm{~m}, 1.35 \mathrm{~m}$ \\
\hline 7 & 32.2 & $1.11 \mathrm{~m}, 1.51 \mathrm{~m}$ & 32.3 & $1.13 \mathrm{~m}, 1.54 \mathrm{~m}$ \\
\hline 8 & 40.2 & & 40.2 & \\
\hline 9 & 46.7 & $1.75 \mathrm{~m}$ & 46.7 & $1.78 \mathrm{~m}$ \\
\hline 10 & 35.9 & & 36.0 & \\
\hline 11 & 23.7 & $1.76 \mathrm{~m}, 1.84 \mathrm{~m}$ & 23.7 & $1.77 \mathrm{~m}, 1.86 \mathrm{~m}$ \\
\hline 12 & 122.9 & 5.35 br s & 122.9 & 5.36 br s \\
\hline 13 & 143.7 & & 143.7 & \\
\hline 14 & 41.6 & & 41.7 & \\
\hline 15 & 35.0 & $1.49 \mathrm{~m}, 1.83 \mathrm{~m}$ & 35.0 & $1.50 \mathrm{~m}, 1.85 \mathrm{~m}$ \\
\hline 16 & 69.9 & 4.60 br s & 70.0 & 4.61 br s \\
\hline 17 & 44.7 & & 44.8 & \\
\hline 18 & 40.8 & $3.05 \mathrm{~m}$ & 40.8 & $3.04 \mathrm{~m}$ \\
\hline 19 & 47.3 & $1.31 \mathrm{~m}, 2.88 \mathrm{~m}$ & 47.4 & $1.32 \mathrm{~m}, 2.89 \mathrm{~m}$ \\
\hline 20 & 32.0 & & 32.0 & \\
\hline 21 & 41.5 & $2.05 \mathrm{~m}, 2.83 \mathrm{~m}$ & 41.6 & $2.05 \mathrm{~m}, 2.83 \mathrm{~m}$ \\
\hline 22 & 72.8 & $6.22 \mathrm{dd}(6.0,12.0)$ & 72.9 & $6.23 \mathrm{dd}(6.0,12.0)$ \\
\hline 23 & 209.9 & $9.91 \mathrm{~s}$ & 210.0 & $9.93 \mathrm{~s}$ \\
\hline 24 & 11.0 & $1.42 \mathrm{~s}$ & 11.0 & $1.46 \mathrm{~s}$ \\
\hline 25 & 15.7 & $0.78 \mathrm{~s}$ & 15.7 & $0.80 \mathrm{~s}$ \\
\hline 26 & 16.7 & $0.81 \mathrm{~s}$ & 17.0 & $0.82 \mathrm{~s}$ \\
\hline 27 & 27.5 & $1.80 \mathrm{~s}$ & 27.5 & $1.81 \mathrm{~s}$ \\
\hline 28 & 63.4 & $3.54 \mathrm{~m}, 3.66 \mathrm{~m}$ & 63.5 & $3.56 \mathrm{~m}, 3.66 \mathrm{~m}$ \\
\hline 29 & 33.4 & $1.05 \mathrm{~s}$ & 33.4 & $1.05 \mathrm{~s}$ \\
\hline 30 & 25.2 & $1.29 \mathrm{~s}$ & 25.2 & $1.29 \mathrm{~s}$ \\
\hline \multicolumn{5}{|l|}{ 22-O-Ang } \\
\hline Ang-1 & 167.9 & & 167.9 & \\
\hline Ang-2 & 129.4 & & 129.4 & \\
\hline Ang-3 & 136.6 & 5.92 (dq-like) & 136.5 & 5.92 (dq-like) \\
\hline Ang-4 & 15.8 & $2.09 \mathrm{~d}(7.2)$ & 15.8 & $2.09 \mathrm{~d}(6.6)$ \\
\hline Ang-5 & 20.9 & $1.95 \mathrm{~s}$ & 20.9 & $1.96 \mathrm{~s}$ \\
\hline
\end{tabular}


Table 1. Cont.

\begin{tabular}{|c|c|c|c|c|}
\hline \multirow{2}{*}{ Position } & \multicolumn{2}{|c|}{ Oleiferasaponin $\mathrm{C}_{4}(\mathbf{1})$} & \multicolumn{2}{|c|}{ Oleiferasaponin $C_{5}(2)$} \\
\hline & $\delta_{\mathrm{C}}$ & $\delta_{\mathbf{H}}$ & $\delta_{\mathrm{C}}$ & $\delta_{\mathbf{H}}$ \\
\hline $3-O-$ & & & & \\
\hline GlcA-1' & 103.9 & $4.80 \mathrm{~d}(7.2)$ & 103.7 & $4.83 \mathrm{~d}(7.2)$ \\
\hline GlcA-2' & 78.4 & $4.61 \mathrm{~m}$ & 78.1 & $4.25 \mathrm{~m}$ \\
\hline GlcA-3' & 83.9 & $4.36 \mathrm{~m}$ & 87.4 & $4.17 \mathrm{~m}$ \\
\hline GlcA-4' & 70.4 & $4.37 \mathrm{~m}$ & 71.3 & $4.30 \mathrm{~m}$ \\
\hline GlcA-5' & 76.9 & $4.11 \mathrm{~m}$ & 76.2 & $4.36 \mathrm{~m}$ \\
\hline GlcA-6 ${ }^{\prime}$ & 170.0 & & 169.8 & \\
\hline COOMe & 52.1 & $3.69 \mathrm{~s}$ & 52.1 & $3.69 \mathrm{~s}$ \\
\hline Gal-1" & 103.1 & $5.79 \mathrm{~d}(7.8)$ & 104.3 & $5.50 \mathrm{~d}(7.8)$ \\
\hline Gal-2" & 73.6 & $4.50 \mathrm{~m}$ & 73.6 & $4.46 \mathrm{~m}$ \\
\hline Gal-3" & 74.8 & $4.33 \mathrm{~m}$ & 75.3 & $4.11 \mathrm{~m}$ \\
\hline Gal- $4^{\prime \prime}$ & 70.3 & $4.47 \mathrm{~m}$ & 70.0 & $4.44 \mathrm{~m}$ \\
\hline Gal-5" & 76.3 & $4.23 \mathrm{~m}$ & 76.7 & $3.96 \mathrm{~m}$ \\
\hline Gal-6" & 61.7 & $4.00 \mathrm{~m}, 4.35 \mathrm{~m}$ & 61.9 & $4.45 \mathrm{~m}, 4.53 \mathrm{~m}$ \\
\hline Gal-1"' & 101.6 & $5.75 \mathrm{~d}(7.2)$ & 105.1 & $5.19 \mathrm{~d}(7.2)$ \\
\hline Gal-2"'l' & 83.5 & $4.55 \mathrm{~m}$ & 72.9 & $4.49 \mathrm{~m}$ \\
\hline Gal-3"' & 75.1 & $4.31 \mathrm{~m}$ & 75.5 & $4.12 \mathrm{~m}$ \\
\hline Gal-4"' & 69.6 & $4.51 \mathrm{~m}$ & 70.1 & $4.57 \mathrm{~m}$ \\
\hline Gal-5"' & 76.5 & $4.46 \mathrm{~m}$ & 77.3 & $4.10 \mathrm{~m}$ \\
\hline Gal-6"' & 62.2 & $4.50 \mathrm{~m}, 4.55 \mathrm{~m}$ & 61.9 & $4.31 \mathrm{~m}, 4.35 \mathrm{~m}$ \\
\hline Glc- $1^{\prime \prime \prime \prime}$ & 106.9 & $5.13 \mathrm{~d}(7.8)$ & & \\
\hline Glc- $2^{\prime \prime \prime \prime}$ & 76.3 & $4.28 \mathrm{~m}$ & & \\
\hline Glc- $3^{\prime \prime \prime \prime}$ & 78.5 & $3.74 \mathrm{~m}$ & & \\
\hline Glc- $4^{\prime \prime \prime \prime}$ & 71.2 & $4.36 \mathrm{~m}$ & & \\
\hline Glc- $5^{\prime \prime \prime \prime}$ & 78.3 & $4.12 \mathrm{~m}$ & & \\
\hline Glc- $6^{\prime \prime \prime \prime}$ & 62.4 & $4.39(2 \mathrm{H}, \mathrm{m})$ & & \\
\hline
\end{tabular}

${ }^{1} \mathrm{H}(\delta$ ppm, J Hz, s: singlet; d: doublet; brs: broad singlet; m: multiplet). Ang: angeloyl; GlcA: glucuronic acid; Gal: galactose; Glc: glucose.

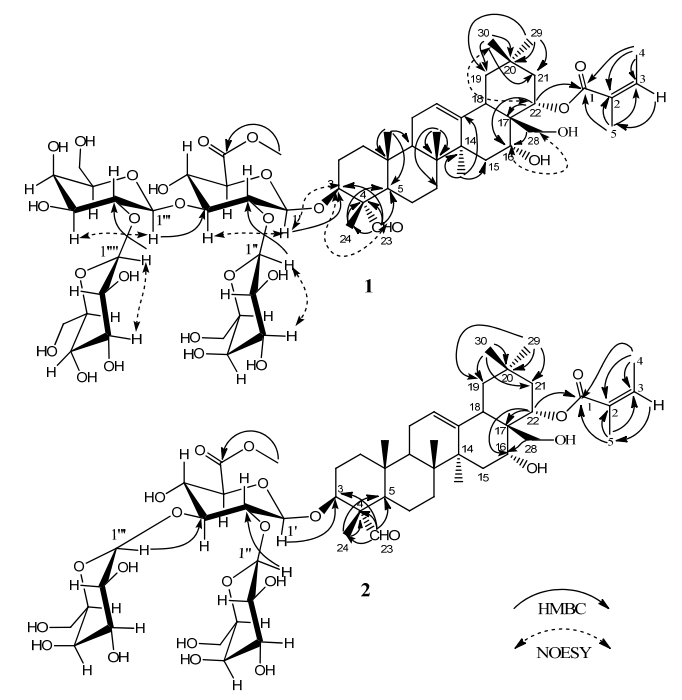

Figure 2. Key HMBC and NOESY correlations within oleiferasaponins $C_{4}$ and $C_{5}(\mathbf{1}, \mathbf{2})$.

Compound 2 was separated as a white amorphous powder. The molecular formula $\mathrm{C}_{54} \mathrm{H}_{84} \mathrm{O}_{22}$ was deduced from the HR-ESI-MS $[\mathrm{M}+\mathrm{Na}]^{+}$ion at $m / z 1107.5358$. The IR spectrum $\left(\mathrm{cm}^{-1}\right)$ showed the presence of hydroxyl (broad peak around 3416), carbonyl (1739), olefinic (1641), and ether $(1077,1045)$ functional groups. The NMR (Table 1) data of 2 were similar to those of $\mathbf{1}$, except 
for the absence of the glucose sugar unit at C-2"' of the galactose moiety. This means that there are only three sugar units in the glycosidic chain of compound 2 (Table 1). The anomeric proton signals were at $\delta_{\mathrm{H}} 4.83\left(1 \mathrm{H}, \mathrm{d}, J=7.2 \mathrm{~Hz}, \mathrm{H}-1^{\prime}\right.$ of glucuronic acid), $5.19\left(1 \mathrm{H}, \mathrm{d}, J=7.2 \mathrm{~Hz}, \mathrm{H}-1^{\prime \prime \prime}\right.$ of glucose), and $5.50\left(1 \mathrm{H}, \mathrm{d}, J=7.8 \mathrm{~Hz}, \mathrm{H}-1^{\prime \prime}\right.$ of galactose) and showed the HSQC correlation to $\delta_{\mathrm{C}} 103.7$ (C-1' of glucuronic acid), 105.1 (C-1"' of galactose), and 104.3 (C-1" $1^{\prime \prime}$ of galactose), respectively. The HMBC (Figure 2) correlations were between GlcA-H-1 ${ }^{\prime}$ and $\delta_{\mathrm{C}} 84.5$ (C-3 of the aglycone), Gal-H- $1^{\prime \prime}$ and $\delta_{\mathrm{C}} 78.1$ (GlcA-C-2'), and Gal-H-1 ${ }^{\prime \prime \prime}$ and $\delta_{\mathrm{C}} 87.4$ (GlcA-C-3'). In addition, the data of 2 was further confirmed by acid hydrolysis and GC-MS analysis, which revealed one unit of D-glucuronic acid methyl ester and two units of D-galactose. Consequently, the structure of 2 was determined to be $16 \alpha$-hydroxy-22 $\alpha$-O-angeloyl-23 $\alpha$-aldehyde-28-dihydroxymethylene-olean-12-ene-3 $\beta$-O-[ $\beta$-Dgalactopyranosyl-( $1 \rightarrow 2)]$-[ $\beta$-D-galactopyranosyl-( $1 \rightarrow 3)]-\beta-D-$ glucopyranosiduronic acid methyl ester, also a new compound that we named oleiferasaponin $C_{5}$.

\subsection{Anti-Proliferative Assay on Human Tumor Cells}

The isolated Compounds 1, 2 and total seed cake saponins (C. oleifera) were tested against five human tumor cell lines (human hepatocellular carcinoma cells BEL-7402, human gastric carcinoma cells BGC-823, human breast cancer cells MCF-7, human promyelocytic leukemia cells HL-60 and human oral epidermoid carcinoma cells KB) using the MTT in vitro assay. Taxol, an anticancer agent, was used as the positive control. Both oleanane-type saponins exhibited effective anti-proliferative activity against the human tumor cell lines tested, especially compound 2. Compound 2 showed potent anti-proliferative activities, with $\mathrm{IC}_{50}$ values ranging from 1.8 to $5.5 \mu \mathrm{M}$, while compound 1 displayed anti-proliferative activity with $\mathrm{IC}_{50}$ values between 6.5 and $15.1 \mu \mathrm{M}$. Total saponins showed anti-proliferative activity with $\mathrm{IC}_{50}$ values between 6.0 and $19.8 \mu \mathrm{M}$ (Table 2).

Table 2. Anti-proliferative activity for compounds 1, 2 and total saponins of C. oleifera against five human tumor cell lines.

\begin{tabular}{cccccc}
\hline \multirow{2}{*}{ Compound } & \multicolumn{5}{c}{ Cell Lines IC } \\
& BEL-7402 & BGC-823 & MCF-7 & HL-60 & KB \\
\cline { 2 - 6 } & 10.385 & 11.242 & 15.094 & 6.489 & 12.302 \\
$\mathbf{1}(\mu \mathrm{M})$ & 4.218 & 5.505 & 3.915 & 1.797 & 3.468 \\
\hline $\mathbf{2}(\mu \mathrm{M})$ & 11.023 & 5.981 & 10.611 & 12.546 & 19.761 \\
\hline Total Saponins $(\mu \mathrm{g} / \mathrm{mL})$ & Taxol was used as a positive control.
\end{tabular}

The structure-activity relationships were inferred by comparison of the structure and the anti-proliferative activities on five human tumor cell lines. Compounds $\mathbf{1}$ and $\mathbf{2}$ have the same aglycone, but compound 2 lacks the glucose sugar moiety at position Gal-C- $2^{\prime \prime \prime}$. The higher anti-proliferative activities of $\mathbf{2}$ compared with those of $\mathbf{1}$ on all of the tested tumor cell lines suggested that three saccharide units (rather than four saccharide units) leads to an increase in the biological potency. The results are consistent with $\mathrm{Mu}$ et al. [15]. In comparison with those of previously reported compounds [10], it seems that the Ang group at position C-22 and the free hydroxy group at C-28 in compound 2 may also play important roles in cytotoxicity. These results further support the idea that the anti-proliferative activity of saponins depends not only on isolated structural factors but also on combinatorial properties of both the aglycone and the sugar moieties.

\section{Materials and Methods}

\subsection{General Information}

The following spectroscopic instruments were used to obtain physical data on the two new isolated saponins: ${ }^{1} \mathrm{H}$ - and ${ }^{13} \mathrm{C}-\mathrm{NMR},{ }^{1} \mathrm{H}-{ }^{1} \mathrm{H}$ COSY, HSQC, HMBC and NOESY spectra were recorded 
in $\mathrm{C}_{5} \mathrm{D}_{5} \mathrm{~N}$ using a DD2 $(600 \mathrm{MHz})$ spectrometer (Agilent, Palo Alto, CA, USA) operating at $600 \mathrm{MHz}$ for ${ }^{1} \mathrm{H}$ and $150 \mathrm{MHz}$ for ${ }^{13} \mathrm{C}$. Coupling constants were expressed in $\mathrm{Hz}$ and chemical shifts were given on a $\delta(\mathrm{ppm})$ scale with tetramethylsilane (TMS) as an internal standard. HR-ESI-MS spectra were determined on an Electrostatic Field Orbital Trap Mass Spectrometer (Thermo Scientific, Bremen, Germany) using an ESI source. IR was measured on a Nicolet 8700 FT-IR spectrophotometer (Thermo Scientific Instrument Co., Boston, MA, USA). The HPLC analyses were performed with Agilent Zorbax Eclipse Plus $\mathrm{C}_{18}$ HPLC column (250 mm $\times 4.6 \mathrm{~mm}$ i.d., $5 \mu \mathrm{m}$, Agilent Corp., Palo Alto, CA, USA) on an HPLC system composed of an LC-20AD pump with an SPD-M20A detector (Shimadzu Corp., Kyoto, Japan). The HPLC purifications were performed with a YMC-Pack ODS-A semi-preparative

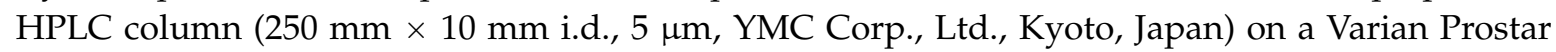
HPLC instrument (Model 325) (Varian, Mulgrave, Australia) and an Agilent Zorbax Eclipse Plus $\mathrm{C}_{18}$ HPLC column on a Waters 2695 separation module combined with a Waters 2489 UV detector (Milford, MA, USA) with the detection wavelengths at 210 and $280 \mathrm{~nm}$. GC-MS analyses were conducted on a GCMS-QP2010S (Shimadzu Corp., Kyoto, Japan) with DB-5MS column (i.d. $=0.25 \mu \mathrm{m}$, length = $30 \mathrm{~m}$, Agilent Technologies). Column chromatography resins were silica gel (100-200 mesh, Qingdao Marine Chemical Co. Ltd., Qingdao, China) and Sephadex LH-20 (25-100 m, Pharmacia Fine Chemical Co. Ltd., Uppsala, Sweden). Thin-layer chromatography (TLC) used precoated silica gel GF254 plates (Qingdao Marine Chemical Co. Ltd., Qingdao, China) and detection by spraying with 5\% vanillin in $10 \% \mathrm{H}_{2} \mathrm{SO}_{4}$-EtOH solution, followed by heating.

\subsection{Plant Materials}

Tea seed cakes of $C$. oleifera were obtained from a commercial tea oil producer in the city of Huangshan in Anhui Province, China. The samples had been defatted according to Lee et al. [16].

\subsection{Extraction and Isolation}

The tea seed cake $(2.0 \mathrm{~kg}$ ) was crushed into powder and extracted three times with $70 \% \mathrm{EtOH}$ $(3 \times 10 \mathrm{~L})$ at $60^{\circ} \mathrm{C}$ under reflux each for $4 \mathrm{~h}$. The extract was subjected to reduced pressure evaporation to obtain a concentrated EtOH solution $(350 \mathrm{~g})$. The concentrated solution was extracted successively with petroleum ether, EtOAc and $n-\mathrm{BuOH}$. The $n$-BuOH fraction $(80 \mathrm{~g})$ was subjected to silica gel (100-200 mesh, $2.0 \mathrm{~kg})$ column chromatography $(70 \mathrm{~mm} \times 600 \mathrm{~mm})$ and eluted with stepwise gradients of EtOAc and MeOH (100:0, 90:10, 80:20, 70:30, 60:40, 50:50, 40:60, 30:70, 20:80, 10:90, 0:100, each $8.0 \mathrm{~L})$. Each fraction was collected and analyzed by TLC. Fractions with similar $\mathrm{R}_{\mathrm{f}}$ values were combined, yielding eight major fractions $(\mathrm{A}-\mathrm{H})$. Fraction $\mathrm{G}(6.5 \mathrm{~g})$ was submitted to gel permeation chromatography on Sephadex LH-20 $(50 \mathrm{~mm} \times 400 \mathrm{~mm})$ in $\mathrm{MeOH}$ to remove the pigments and flavones and yielded four major fractions (I-IV). Fraction II (2.0 g) was further subjected to semi-preparative HPLC (YMC-Pack ODS-A, $250 \mathrm{~mm} \times 10 \mathrm{~mm}$ i.d., $5 \mu \mathrm{m}, \mathrm{CH}_{3} \mathrm{CN}-0.5 \%$ aqueous $\mathrm{HCOOH}(40: 60, v / v)$, $2 \mathrm{~mL} / \mathrm{min})$ to yield five fractions [Fr. 1 (0.83 g), Fr. 2 (0.12 g), Fr. 3 (0.06 g), Fr. 4 (0.11 g), and Fr. $5(0.55 \mathrm{~g})$ ]. Fractions 2 and 3 were further purified by HPLC [Agilent $\mathrm{C}_{18}, 250 \mathrm{~mm} \times 4.6 \mathrm{~mm}$ i.d., $5 \mu \mathrm{m}, \mathrm{CH}_{3} \mathrm{CN}-0.5 \%$ aqueous $\left.\mathrm{HCOOH}(42: 58, v / v), 1 \mathrm{~mL} / \mathrm{min}\right]$ to afford Compounds $1(8.0 \mathrm{mg})$ and 2 (5.2 mg).

\subsection{Spectroscopic Data}

Oleiferasaponin $\mathrm{C}_{4}(\mathbf{1})$ : white amorphous powder; UV (MeOH) $\lambda_{\max } \mathrm{nm}(\log \varepsilon)$ : 239 (4.16), 278 (4.28); IR (KBr) $v_{\max }\left(\mathrm{cm}^{-1}\right): 3416,2951,2927,1740,1719,1640,1441,1385,1242,1160,1078$, 1044; ${ }^{1} \mathrm{H}-\mathrm{NMR}$ (pyridine- $d_{5}$ ) and ${ }^{13} \mathrm{C}-\mathrm{NMR}$ (pyridine- $d_{5}$ ) spectroscopic data, see Table 1 ; HR-ESI-MS (positive ion mode): $m / z 1269.5875[\mathrm{M}+\mathrm{Na}]^{+}$(calcd for $\mathrm{C}_{60} \mathrm{H}_{94} \mathrm{O}_{27} \mathrm{Na}, 1269.5880$ ), the data was shown in supplementary materials.

Oleiferasaponin $\mathrm{C}_{5}$ (2): white amorphous powder; UV (MeOH) $\lambda_{\max } \mathrm{nm}(\log \varepsilon): 209$ (3.91), 280 (4.27); IR (KBr) $v_{\max }\left(\mathrm{cm}^{-1}\right): 3416,2927,1739,1720,1641,1442,1385,1242,1162,1077,1045$; ${ }^{1} \mathrm{H}-\mathrm{NMR}$ (pyridine- $d_{5}$ ) and ${ }^{13} \mathrm{C}-\mathrm{NMR}$ (pyridine- $d_{5}$ ) spectroscopic data, see Table 1 ; HR-ESI-MS (positive 
ion mode): $m / z 1107.5356[\mathrm{M}+\mathrm{Na}]^{+}\left(\right.$calcd for $\left.\mathrm{C}_{54} \mathrm{H}_{84} \mathrm{O}_{22} \mathrm{Na}, 1107.5352\right)$, the data was shown in supplementary materials.

\subsection{Acid hydrolysis and GC-MS Analysis of the Sugar Moieties in $\mathbf{1}$ and $\mathbf{2}$}

Each saponin $(0.8 \mathrm{mg})$ was dissolved in $1 \mathrm{M} \mathrm{HCl}(1 \mathrm{~mL})$ for $3 \mathrm{~h}$ at $90{ }^{\circ} \mathrm{C}$. The reaction mixture was extracted with chloroform, and the supernatant was evaporated to dryness under $\mathrm{N}_{2}$ flow. The residue was dissolved in $0.2 \mathrm{~mL}$ of pyridine containing L-cysteine methyl ester hydrochloride $(10 \mathrm{mg} / \mathrm{mL})$ and reacted at $70{ }^{\circ} \mathrm{C}$ for $1 \mathrm{~h}$. This reaction was evaporated under $\mathrm{N}_{2}$ flow, after which $0.2 \mathrm{~mL}$ trimethylsilylimidazole (Adamas Reagent Co., Ltd, Shanghai, China) was added. The mixture was heated at $70{ }^{\circ} \mathrm{C}$ for another $1 \mathrm{~h}$, and then partitioned between $n$-hexane and water. The organic phase was analyzed by GC-MS. Temperature conditions were as follows: injector temperature at $280{ }^{\circ} \mathrm{C}$; the initial oven temperature was $160{ }^{\circ} \mathrm{C}$ for $1 \mathrm{~min}$, then linearly increased to $200{ }^{\circ} \mathrm{C}$ at $6{ }^{\circ} \mathrm{C} / \mathrm{min}$. A further linear increase at $3{ }^{\circ} \mathrm{C} / \mathrm{min}$ was performed to $280{ }^{\circ} \mathrm{C}$, which was held for $5 \mathrm{~min}$. The standard sugar samples were subjected to the same reaction and GC-MS conditions. The sugar units of compounds $\mathbf{1}$ and $\mathbf{2}$ were identified by comparison with authentic samples: D-xylose $\left(t_{R} 16.93 \mathrm{~min}\right), \mathrm{D}$-glucose ( $\left.t_{R} 21.67 \mathrm{~min}\right)$, D-galactose ( $\left.t_{R} 22.31 \mathrm{~min}\right), \mathrm{D}$-glucuronic acid methyl ester $\left(t_{R} 23.34 \mathrm{~min}\right)$. D-glucose, D-galactose and D-glucuronic acid methyl ester were identified in a ratio of 1:2:1 for compound 1, D-galactose and D-glucuronic acid methyl ester were identified in a ratio of 2:1 for 2 .

\subsection{Anti-Proliferative Activity Assay in Vitro}

The procedure for the anti-proliferative activity assay was performed according to the MTT reduction method using the human tumor cell lines BEL-7402, BGC-823, MCF-7, HL-60 and KB (Nanjing KeyGEN BioTECH Co., LTD, Jiangsu, China). In brief, the human tumor cell lines in culture medium $(100 \mu \mathrm{L})$ were placed in a cell of a 96-well plate at a concentration of $4 \times 10^{3}$ cells $/ \mathrm{mL}$ and incubated at $37{ }^{\circ} \mathrm{C}$ in $5 \% \mathrm{CO}_{2}$ for $24 \mathrm{~h}$. After $24 \mathrm{~h}$, an additional $100 \mu \mathrm{L}$ of complete medium with either: no additions (negative control), $0.1 \%$ DMSO (solvent control), $10 \mu \mathrm{g} / \mathrm{mL}$ Taxol (positive control), or different concentrations $(0.391,0.781,1.562,3.125,6.25,12.5,25$ and $50 \mu \mathrm{M})$ of 1 or 2 or total saponins $(0.391,0.781,1.562,3.125,6.25,12.5,25$ and $50 \mu \mathrm{g} / \mathrm{mL})$. The treated cells were incubated as above for $72 \mathrm{~h}$. Then, $20 \mu \mathrm{L}$ of MTT solution $(5 \mathrm{mg} / \mathrm{mL})$ were added to the culture medium, and the reaction mixture was incubated as above for $4 \mathrm{~h}$. After $4 \mathrm{~h}$, the medium was discarded and $150 \mu \mathrm{L}$ DMSO were added. The optical density (OD) of each well was measured at $490 \mathrm{~nm}$ using a Tunable Microplate Reader (EL-x800, BioTek Instruments, Winooski, VT, USA). The results were expressed as concentrations of compound producing $50 \%$ toxicity ( $\mathrm{IC}_{50}$ value).

\section{Conclusions}

Two new oleanane-type saponins, namely oleiferasaponins $C_{4}$ and $C_{5}(\mathbf{1}, \mathbf{2})$, were isolated from the seed cake of Camellia oleifera Abel. and identified. The anti-proliferative activity of the two compounds were investigated on five human tumor cell lines (BEL-7402, BGC-823, MCF-7, HL-60 and KB) and exhibited potent cytotoxic activities, especially compound 2.

Supplementary Materials: Supplementary materials can be accessed at: http:/ /www.mdpi.com/1420-3049/21/ 2/188/s1. HR-ESR-MS and NMR spectra data of compounds 1 and 2 as supporting information.

Acknowledgments: This research was supported by projects of "Nutrition and Quality \& Safety of Agricultural Products, Universities Leading Talent Team of Anhui Province"; the Earmarked Fund for Modern Agro-industry Technology Research System in Tea Industry of Chinese Ministry of Agriculture (nycytx-26) and Natural Science Foundation for Distinguished Young Scholars of Anhui Province (1608085J08). We sincerely thank Jingwei Hu, at the Center of Biology Technology at Anhui Agricultural University for NMR measurements.

Author Contributions: In this paper, R.-Y.H., X.-C.W. and J.-F.Z. designed the study; J.-F.Z., Y.-R.P. and G.-H.B. performed research and analyzed the data; J.-F.Z. wrote the paper. All authors read and approved the final manuscript. 
Conflicts of Interest: The authors declare no conflict of interest.

\section{References}

1. Kuo, P.C.; Lin, T.C.; Yang, C.W.; Lin, C.L.; Chen, G.F.; Huang, G.W. Bioactive saponin from tea seed pomace with inhibitory effects against Rhizoctonia. solani. J. Agric. Food Chem. 2010, 58, 8618-8622. [PubMed]

2. Hu, J.L.; Nie, S.P.; Huang, D.F.; Li, C.; Xie, M.Y.; Wan, Y. Antimicrobial activity of saponin-rich fraction from Camellia oleifera cake and its effect on cell viability of mouse macrophage RAW 264.7. J. Sci. Food Agric. 2012, 92, 2443-2449. [CrossRef] [PubMed]

3. Zhang, X.F.; Yang, S.L.; Han, Y.Y.; Zhao, L.; Lu, G.L.; Xia, T.; Gao, L.P. Qualitative and Quantitative Analysis of Triterpene Saponins from Tea Seed Pomace (Camellia oleifera Abel) and Their Activities against Bacteria and Fungi. Molecules 2014, 19, 7568-7580. [PubMed]

4. Hu, J.L.; Nie, S.P.; Huang, D.F.; Li, C.; Xie, M.Y. Extraction of saponin from Camellia oleifera cake and evaluation of its antioxidant activity. Int. J. Food Sci. Technol. 2012, 47, 1676-1687.

5. Sugimoto, S.; Chi, G.; Kato, Y.; Nakamura, S.; Matsuda, H.; Yoshikawa, M. Medicinal Flowers. XXVI. Structures of Acylated Oleanane-Type Triterpene Oligoglycosides, Yuchasaponins A, B, C, and D, from the Flower Buds of Camellia oleifera-Gastroprotective, Aldose Reductase Inhibitory, and Radical Scavenging Effects-. Chem. Pharm. Bull. 2009, 57, 269-275. [CrossRef] [PubMed]

6. Jian, H.L.; Liao, X.X.; Zhu, L.W.; Zhang, W.M.; Jiang, J.X. Synergism and foaming properties in binary mixtures of a biosurfactant derived from Camellia oleifera Abel and synthetic surfactants. J. Colloid Interface Sci. 2011, 359, 487-492. [PubMed]

7. Chen, Y.Z.; Ma, L.; Liu, Z.C.; Peng, S.F.; Chen, X.L.; Chen, L.S.; Wang, X.N.; Wang, R. Molluscicidal effect of Camellia oleifera saponin. J. Central South. Univ. For. Technol. 2011, 31, 147-150.

8. Chen, Y.F.; Yang, C.H.; Chang, M.S.; Ciou, Y.P.; Huang, Y.C. Foam Properties and Detergent Abilities of the Saponins from Camellia oleifera. Int. J. Mol. Sci. 2010, 11, 4417-4425. [PubMed]

9. Chen, L.Y.; Chen, J.; Xu, H.H. Sasanquasaponin from Camellia oleifera Abel. induces cell cycle arrest and apoptosis in human breast cancer MCF-7 cells. Fitoterapia 2013, 84, 123-129. [PubMed]

10. Zong, J.F.; Wang, R.L.; Bao, G.H.; Ling, T.J.; Zhang, L.; Zhang, X.F.; Hou, R.Y. Novel Triterpenoid Saponins from Residual Seed Cake of Camellia oleifera Abel. show Anti-proliferative Activity against Tumor Cells. Fitoterapia 2015, 104, 7-13. [PubMed]

11. Li, X.; Zhao, J.P.; Peng, C.P.; Chen, Z.; Liu, Y.L.; Xu, Q.M.; Khan, I.A.; Yang, S.L. Cytotoxic Triterpenoid Glycosides from the Roots of Camellia oleifera. Planta Med. 2014, 80, 590-598. [CrossRef] [PubMed]

12. Zhou, H.; Wang, C.Z.; Ye, J.Z.; Chen, H.X. New triterpene saponins from the seed cake of Camellia oleifera and their cytotoxic activity. Phytochem. Lett. 2014, 8, 46-51.

13. Chen, J.H.; Wu, H.Y.; Liau, B.C.; Chang, C.M.J.; Jong, T.T.; Wu, L.C. Identification and evaluation of antioxidants defatted Camellia oleifera seeds by isopropanol salting-out pretreatment. Food Chem. 2010, 121, 1246-1254. [CrossRef]

14. Zhang, X.F.; Han, Y.Y.; Bao, G.H.; Ling, T.J.; Zhang, L.; Gao, L.P.; Xia, T. A new saponin from tea seed pomace (Camellia oleifera Abel) and its protective effect on PC12 Cells. Molecules 2012, 17, 11721-11728. [PubMed]

15. Mu, L.H.; Huang, C.L.; Zhou, W.B.; Guo, D.H.; Liu, P. Methanolysis of triterpenoid saponin from Ardisia. gigantifolia stapf. and structure-activity relationship study against cancer cells. Bioorg. Med. Chem. Lett. 2013, 23, 6073-6078. [PubMed]

16. Lee, S.Y.; Jung, M.Y.; Yoon, S.H. Optimization of the Refining Process of Camellia Seed Oil for Edible Purposes. Food Sci. Biotechnol. 2014, 23, 65-73.

Sample Availability: Not available.

(C) 2016 by the authors; licensee MDPI, Basel, Switzerland. This article is an open access article distributed under the terms and conditions of the Creative Commons by Attribution (CC-BY) license (http:/ / creativecommons.org/licenses/by/4.0/). 